\title{
THE ROYAL SOCIETY OF
}

\section{EDINBURGH}

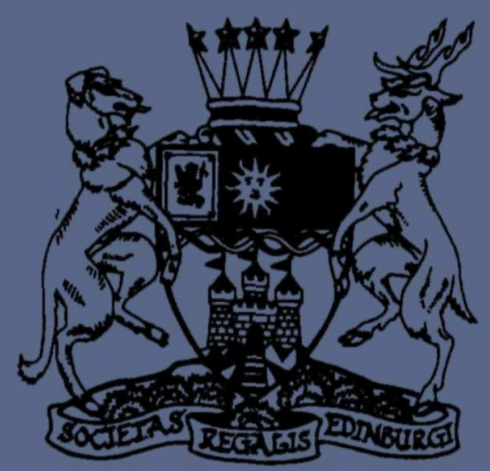

PROCEEDINGS SECTION A M A T H E M A T I C S

PUBLISHED BY THE ROYAL SOCIETY OF EDINBURGH 22 GEORGE STREET, EDINBURGHEH 22 PQ 


\title{
EDITORIAL BOARD
}

\section{Executive Editors}

\author{
J. CARR
}

Heriot-Watt University

\section{A. M. DAVIE \\ University of Edinburgh}

\author{
T. J. LYONS \\ Imperial College, London
}

J. C. EILBECK

Heriot-Watt University

W. N. EVERITT

University of Birmingham

J. R. HUBBUCK

University of Aberdeen

A. J. R. G. MILNER

University of Edinburgh

A. A. RANICKI

University of Edinburgh
B. StRaughan

University of Glasgow

A. Truman

University College, Swansea
F. Willett

Curator

Glasgow

\section{Consulting Editors}

\section{H. BREZIS}

Université de Paris VI

C. M. DAFERMOS

Brown University,

Providence, RI, USA

S. K. DONALDSON

University of Oxford

R. G. DOUGLas

State University of New York at

Stony Brook, USA

L. E. FraENKEL

University of Bath

M. GIAQUINTA

Università degli

Studi di Firenze

J. K. Hale

Georgia Institute of Technology,

USA

K. KIRCHGASSNER

Universität Stuttgart

ROBERT V. KOHN

New York University

P. L. LIONS

Université de Paris IX

H. Matano

University of Tokyo,

Japan

M. MimURA

Okayama University, Japan

\author{
O. A. OleINIK \\ Moscow State University, \\ USSR \\ A. Yu. OlshanskiI \\ Moscow State University, \\ Russia \\ D. S. Passman \\ University of Wisconsin- \\ Madison \\ J. M. SANZ-SERNA \\ Universidad de Valladolid, Spain \\ W. G. STRANG \\ Massachusetts Institute of \\ Technology, Cambridge, USA \\ C. A. STUART \\ École Polytechnique Fédérale \\ de Lausanne \\ L. TARTAR \\ Carnegie-Mellon University, \\ Pittsburgh, USA \\ J. TOLAND \\ University of Bath \\ N. S. TRUDINGER \\ Australian National University, \\ Canberra, Australia \\ G. Q. ZHANG \\ Peking University, Beijing \\ W. A. ZHENG \\ University of California, Irvine, USA
}

Publications Manager, Royal Society of Edinburgh: T. G. Dart

The Royal Society of Edinburgh Proceedings Section A Mathematics is published every two months by the Royal Society of Edinburgh. Subscription price is $£ 192.00$ for six issues (vol. 124). Orders, claims etc. should be addressed to CAB International, Wallingford, Oxon OX10 8DE, U.K. (Tel: (0491) 832111; Fax (0491) 826090)

Second Class postage pending at Jamaica, N.Y., Postmaster send address corrections to The Royal Society of Edinburgh Proceedings Section A Mathematics, c/o IMD, 14905 177th St, Jamaica, N.Y. 11434, U.S.A. 